\title{
Prostitution and Human Trafficking
}

\author{
Luca Luccitelli $i^{\bullet}$
}

\section{Riassunto}

L'autore analizza l'attività dell'associazione Comunità Papa Giovanni XXIII, presso cui egli lavora, relativa alla liberazione di migliaia di vittime del traffico di esseri umani e alla lotta contro la prostituzione.

In particolare, egli illustra i metodi di intervento ed esamina alcuni dati sulle persone trafficate e sui clienti delle prostitute. Infine, vengono riportati alcuni modelli legislativi sulla prostituzione in Europa.

\section{Résumé}

L'auteur analyse les activités d'une association : la communauté Pape Jean XXIII, où il travaille pour la libération des milliers de victimes de la traite des êtres humains et la lutte contre la prostitution.

Plus précisément, il décrit les méthodes employées et présente quelques données sur les personnes victimes de la traite des êtres humains et sur les clients des prostituées.

En conclusion, il examine brièvement certains modèles de lois sur la prostitution en Europe.

\section{Abstract}

The author analyses the activity of an association: the Community Pope John XXIII, where he works on the liberation of thousands of victims of human trafficking and the fight against prostitution.

More specifically, he describes the methods of intervention and provides some data about people who are trafficked for and clients of prostitutes.

In conclusion, some legislation models about prostitution in Europe are briefly discussed.

Key words: Community Pope John XXIII; prostitution; human trafficking; legislation models.

\footnotetext{
• Association Comunità Papa Giovanni XXIII, Italy.
} 


\section{Introduction.}

The Association Comunità Papa Giovanni XXIII ${ }^{1}$ was founded in Italy by Father Oreste Benzi, an Italian Catholic Priest, in the early 1960s. The Association is now present in thirty-two different countries on five continents. The specific missions of the members are to share their lives directly with the poor and the least priviliged and help to remove the causes of injustice.

We are known for our family homes. A "family home" is a residential and educational community, made like a natural family in all possible ways. It is characterised by the stable presence of two parental figures - a mother and a father, or at least one of them - who chose to share their life in a continuous and self-giving way with people in need.

In 2006, the Association was granted Special Consultative Status by the Economic and Social Council (ECOSOC) of the United Nations.

Among the different activities of the Community, it is important to mention the activities done in order to liberate thousands of victims from prostitution and human trafficking.

In 1989, Father Oreste Benzi met a prostitute at Rimini railway station: this meeting revealed to him the horror of forced prostitution and the conditions of oppression hidden behind it.

\section{Method of intervention.}

Our method of intervention is the following:

\section{Emergence.}

First of all, we help forced prostitutes to free themselves from traffickers through our street education workers. They work in small groups composed of three or four people (at least one of them must be a woman) in order to implement interventions in areas where at night forced prostitutes are present. These social workers propose them to get out of the oppression in which they are living.

Nowadays, we have eighteen street education teams, made up of about ninety volounteers, operating from Northern to Southern Italy.

\section{The first welcome.}

Women who want to get out of prostitution take refuge in our family and refugee homes. We are committed to meet their first needs (medical and psychological care, language problem, legal assistance).

\section{Rehabilitation.}

After obtaining the special humanitarian resident permit (awarded pursuan to the Law No 286/1998, article No 18), we provide training and employment opportunities with the aim of making women independent and start a new life.

These activities have permitted over 6,000 women released from sexual slavery to take refuge in our organisations.

At present, our social protection programme takes care of 230 victims of human trafficking. Every week we meet hundreds of women on the Italian streets, through our street education teams. Last but not least, we carry on working on advocacy inside Italian Parliament and Government in order to address, reduce and discourage the demand that fosters sexual exploitation of women.

We propose to adopt the so-called Nordic model, by penalising clients of prostitutes in order to act as a deterrent to sex trafficking.

\section{Some key findings on human trafficking.}

This is a short synthesis of some key findings on human trafficking:

\footnotetext{
${ }^{1}$ See the webpage: www.apg23.org
} 
- Women constitute the majority of those who are trafficked, very often for purposes of sexual exploitation: they account for 5560 percent of total victims; women and girls account together for 75 percent.

- Trafficking for the purpose of sexual exploitation account for 58 percent of total trafficking. Between 2000 and 2009, the percentage of children trafficked rose from 20 to 27 percent.

A brief study of these data shows that:

i. there is a close correlation between women prostitution and human trafficking.

ii. The need to continue to work for protecting women and children.

Italy is a country both of destination and transit of trafficked persons. It is currently believed that there could be between 75,000 and 90,000 victims of prostitution rackets. The basic dimension of the phenomenon is the prostitution in the street, but indoor prostitution is also significant (apartments, night clubs and massage parlours).

The majority of the phenomenon occurs on the road, but it is also relevant indoors (apartments, night clubs or massage parlours). It is also estimated that 10 percent of prostitutes are children. The phenomenon of sexual exploitation of children is growing. Moreover, there are customers who request pregnant women. The offer adapts quickly based on the changes in demand.

We will now briefly examine some details about the client of prostitutes.

The sex buyers are middle-aged men, often married, who have an active sex life. Through these few words, we understand that clients of prostitutes are not looking only for a sexual performance, but they are interested mainly in dominating by psychological violence.

We believe that today the so-called Merlin's Law would no longer be effective in fighting against forced prostitution.

In our opinion the so-called Merlin Law now is not effective in contrasting forced prostitution.

The fifth paragraph of article 9 of Palermo Protocol explicitly states that: "States Parties shall adopt or strengthen legislative or other measures, such as educational, social or cultural measures, including through bilateral and multilateral cooperation, to discourage the demand that fosters all forms of exploitation of persons, especially women and children, that leads to trafficking".

The Directive 2011/36/EU of the European Parliament ${ }^{2}$ recalls the above-mentioned Protocol and at the fourth paragraph of article 18 states that: "In order to make the preventing and combating of trafficking in human beings more effective by discouraging demand, Member States shall consider taking measures to establish as a criminal offence the use of services which are the objects of exploitation [...]".

In our opinion, the regulation of prostitution is not effective in fighting human trafficking for the following reasons:

a) Legalised prostitution leads to an increase in demand and consequently an increase in human trafficking. It is estimated that roughly 80 percent of women working in the Netherlands in the legalised sex industry have been trafficked from other countries against their will ${ }^{3}$.

\footnotetext{
2 Directive 2011/36/EU of the European Parliament and of the Council of 5 April 2011 on preventing and combating trafficking in human beings and protecting its victims, and replacing Council Framework Decision 2002/629/JHA.

3 Raymond J., "Ten Reasons for Not Legalizing Prostitution, Coalition Against Trafficking in Women",
} 
b) it is difficult to identificate victims of human trafficking. Nowadays modus operandi of pimps has changed through an increase of the remuneration given to prostitutes.

c) does not facilitate prosecution of the pimps. Legalisation of prostitution is an excellent shield for hiding traffickers.

d) does not allow to increase tax revenues because it expands the black market. In Germany, the lawmakers expected hundreds of millions of euros of tax revenues thanks to the legalisation of prostitution. However, due to the criminal nature of prostitution, many brothels refused to pay taxes ${ }^{4}$.

e) Does not reduce the violence against women. In the Netherlands, 60 percent of prostitutes suffered physical assaults, 70 percent experienced verbal threats, 40 percent experienced sexual violence and 40 percent had been forced into prostitution or sexual abuse by acquaintances 5 . In the U.S., 86 percent of prostitutes reported that they were subjected to physical violence by buyers.

f) Does not increase health safety. In the state of Victoria, Australia, one in five clients still request for unsafe sex. In Canada, the Special Committee on Pornography and Prostitution estimated that prostitutes have a mortality rate 40 times higher than the national average ${ }^{6}$.

in Prostitution, Trafficking, and Traumatic Stress, 2003, pp. 315-317.

${ }^{4}$ Hughes D. M., "Don't Legalize: The Czech Republic Proposes a Dutch Solution to Sex Trafficking", The National Review Online, May 11, 2004, http:// www.nationalreview.com/hughes/hughes200405110833. asp

${ }^{5}$ O'Connor M., Healy G., The Links between Prostitution and Sex Trafficking: A Briefing Handbook, 2006 (available at http://www.catwinternational.org/Home/Article/235the-links-between-prostitution-and-sex-trafficking-abriefing-handbook)

${ }^{6}$ Special Committee on Pornography and Prostitution in Canada, Pornography and Prostitution in Canada: Report of the Special Committee on Pornography and Prostitution in Canada, Vols. 1 \& 2, Ottawa, Canada: Supply \& Services, 1985. g) It grows social costs because of the increase of the risk of sexually transmitted infection spreading.

Prostitution itself is an abuse.

A nine country study found that 68 percent of prostitutes met criteria for a diagnosis of posttraumatic stress disorder (PTSD), and symptoms were equal to or greater than those of Vietnam veterans. Symptoms were similar to those of battered women seeking shelter, survivors of rape, and refugees from state-organised torture. These kinds of symptoms have been observed regardless of legalisation or criminalisation of prostitution, and regardless of indoor, in brothels or street prostitution?

On 26 February 2014 European Parliament voted the Honeyball Resolution on "Sexual exploitation and prostitution and their impact on gender equality". Most Members of the European Parliament believe that one of the best ways to combat prostitution and trafficking of women and girls is the so-called Nordic model, followed in Sweden, Iceland and Norway. It views prostitution as a violation of human rights and as a form of violence against women and criminalises those who buy sex rather than those who sell it. They call on EU countries to take the Nordic model as an example.

The message is clear: victims can be freed only by eliminating demand.

\section{Bibliography.}

- Farley M. et al., "Prostitution and Trafficking in Nine Countries: An Update on Violence and Post.traumatic Stress Disorder", in Prostitution, Trafficking, and Traumatic Stress, 2003, pp. 33-49.

\footnotetext{
${ }^{7}$ Farley M. et al., "Prostitution and Trafficking in Nine Countries: An Update on Violence and Post.traumatic Stress Disorder", in Prostitution, Trafficking, and Traumatic Stress, 2003, pp. 33-49.
} 
- Hughes D. M., "Don't Legalize: The Czech Republic Proposes a Dutch Solution to Sex Trafficking", The National Review Online, May 11, 2004 (available at http:// www.nationalreview.com/hughes/hughes20040 5110833.asp).

- O'Connor M., Healy G., The Links between Prostitution and Sex Trafficking: A Briefing Handbook, 2006 (available at http://www.catwinternational.org/Home/Artic le/235-the-links-between-prostitution-and-sextrafficking-a-briefing-handbook).
- Raymond J., "Ten Reasons for Not Legalizing Prostitution, Coalition Against Trafficking in Women", in Prostitution, Trafficking, and Traumatic Stress, 2003

- Special Committee on Pornography and Prostitution in Canada, Pornography and Prostitution in Canada: Report of the Special Committee on Pornography and Prostitution in Canada, Vols. 1 \& 2, Ottawa, Canada: Supply \& Services, 1985. 